\title{
Implementation of the Education and Training Program seen from the CIPPO Perspective
}

\author{
Luthfi Dhimas Widayanto ${ }^{*}$, Soeharto ${ }^{2}$, Putu Sudira ${ }^{3}$, Rihab Wit Daryono4, \\ Muhammad Nurtanto 5 \\ 1,23,4 Department of Technological and Vocational Education, Yogyakarta State University, Yogyakarta, Indonesia \\ ${ }^{5}$ Sultan Ageng Tirtayasa University, Banten, Indonesia
}

\section{A R T I C L E I N F O}

Article history:

Received July 08, 2021

Revised July 10, 2021

Accepted September 24, 2021

Available online November 25, 2021

Kata Kunci :

CIPPO, Pelatihan Berbasis

Kompetensi, Kejuruan

Keywords:

CIPPO, Competency-Based

Training, Vocational

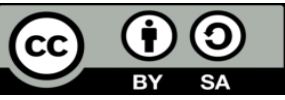

This is an open access article under the CC BY-SA license.

Copyright () 2021 by Author. Published by Universitas Pendidikan Ganesha

\begin{abstract}
A B S T R A K
Peran pemerintah sebagai fasilitator menawarkan program Competency-Based Training (CBT) untuk mengatasi permasalahan tersebut. Program ini diadakan untuk menjawab kebutuhan masyarakat dalam mengembangkan diri untuk menguasai kompetensi tertentu untuk diserap di industri. Penelitian ini bertujuan untuk mengevaluasi capaian pelaksanaan program diklat di UPT BLK Surabaya dan memberikan rekomendasi untuk program diklat selanjutnya. Penelitian ini merupakan penelitian evaluasi dengan menggunakan model CIPPO (context, input, process, product, and outcome). Instrumen penelitian berupa angket yang divalidasi melalui expert judgement, dan diberikan kepada dua kelompok responden yaitu peserta pelatihan dan instruktur. Responden penelitian sebanyak 199 orang yang terdiri dari 180 peserta pelatihan, 19 instruktur. Hasil penelitian adalah sebagai berikut. (1) Aspek konteks yaitu kesesuaian program dengan tujuan lembaga, kebutuhan masyarakat dan industri, dinyatakan baik oleh peserta dan sangat baik oleh pengajar serta didukung dengan kelengkapan dokumen dasar hukum dan karakteristik program pelatihan. (2) Aspek input yaitu sarana prasarana, proses seleksi, kompetensi instruktur, kurikulum, dan dana dinyatakan baik oleh peserta dan sangat baik oleh instruktur. (3) Aspek proses yaitu perencanaan, pelaksanaan, dan pengawasan telah sesuai dengan SOP yang diterapkan oleh pemerintah. Pelaksanaan program pelatihan dinyatakan dengan baik oleh peserta dan instruktur sangat baik. (4) Aspek produk yang merupakan kompetensi peserta dikemukakan dengan sangat baik oleh peserta dan instruktur. (5) Pada aspek outcome, persentase tingkat penyerapan lulusan di sektor bisnis dan sektor industri adalah 37\%. Rekomendasi untuk aspek infrastruktur adalah meningkatkan jumlah dan kebersihan kamar mandi.
\end{abstract}

\section{A B S T R A C T}

The government's role as a facilitator offers Competency-Based Training (CBT) programs to overcome these problems. This program is held to answer the needs of the community to develop themselves to master certain competencies to be absorbed in the industry. This study aims to evaluate the achievement of the implementation of training programs at UPT BLK Surabaya and to provide recommendations for the next training program. This research is evaluation research using the CIPPO (context, input, process, product, and outcome) model. The research instrument is a questionnaire validated through expert judgment, and given to two groups of respondents: the training participants and instructors. The research respondents were 199 consisting of 180 training participants, 19 instructors. The research findings are as follows. (1) The context aspect, which is the suitability of the program with the objectives of the institution, the needs of the community and industry, was stated good by the participants and very good by instructors and supported by the completeness of legal basic documents and the characteristics of the training program. (2) The input aspect, which is infrastructure, selection process, instructors competence, curriculum, and funds were stated well by the participants and very good by instructors. (3) The process aspects, which are planning, implementation, and supervision, are in accordance with the SOP applied by the government. The implementation of the training program was stated well by the participants and very good the instructors. (4) The product aspect, which is the competence of the participants, was stated very well by participants and instructors. (5) In the aspect of outcome, the percentage of the absorption rate of graduates in the business sector and industrial sector is $37 \%$. The recommendation to the aspect of infrastructure is to increase the number and cleanliness of bathrooms.

\section{INTRODUCTION}

Vocational education is one of the formal or non-formal educations to improve skills and competencies in order to get a job (Daryono et al., 2021; Prasojo et al., 2020; Supriyadi et al., 2020; Triyono et al., 2020), improve quality workers (Nurtanto et al., 2020; Pratomo et al., 2020), obtain welfare (Liu et 
al., 2020; Olazaran et al., 2019), so that education will lead to a better direction. Vocational education serves to help improve the quality and competence of the community (Coetzer et al., 2020; Creed et al., 2020; Daryono et al., 2020). One of the government's programs to improve competency and workforce absorption is by providing training through the Work Training Center (WTC). According to the regulation of the Minister of Manpower and Transmigration of the Republic of Indonesia No. 7 of 2012 concerning Cooperation in the Use of Private Job Training Centers, WTC is a place where job training is held for trainees so that they master a certain level of work competence to equip themselves to enter the world of work. The government's role as a facilitator offers Competency-Based Training (CBT) programs to overcome these problems. This program is held to answer the needs of the community to develop themselves to master certain competencies to be absorbed in the industry (Coetzer et al., 2020).

The Unit Pelaksana Teknis Balai Latihan Kerja Surabaya (UPT BLK Surabaya), which is located in the city of Surabaya, East Java, is under the auspices of the East Java Manpower and Transmigration Office. The training carried out is Competency-Based Training (CBT). The CBT program refers to the Indonesian National Work Competency Standards (Standar Kompetensi Kerja Nasional Indonesia-SKKNI). The training program is also based on industry needs to equip graduates (Hofmann et al., 2021; Nopiah et al., 2018). Training participants are expected to have competence after attending the training so that they are able to compete and enter the world of work (García-Castilla et al., 2019; Meo et al., 2020).

The UPT BLK Surabaya organizes training for at least 3 to 5 batches every year, and each class has a maximum of 16 people. Some vocational programs sometimes do not reach the target of the maximum number of classes. In addition, participants who have completed the training program do not go straight to work. Not all graduates participating in the training program get jobs that are in accordance with the vocational field pursued. Whereas the training program is designed to prepare and produce graduates who are competent and ready to work. The training participants took part in a series of training with a syllabus made by UPT BLK Surabaya instructors. The training was held for 240 hours of lessons with five meetings per week. The specified competency standards must be achieved by training participants and are required to master all the competencies taught in the syllabus. In one class there are 16 training participants, a large number of training participants should be balanced with sufficient and adequate practical equipment. Practical equipment must be met properly so that learning can run smoothly, but some of the vocational programs offered do not have adequate practical equipment. Optimal use of practical equipment can help trainees pass the competency test with good results.

Previous research conducted an evaluation study of the workshop entrepreneurship program (Pamungkas \& Fauziah, 2014). The evaluation was conducted using the CIPP model showing that the context, input, process, and product aspects have good criteria. In the context aspect, it was found that the needs and participation of students matched the program with learning needs. However, related to experience, it was found that some of the students did not have basic skills. The input aspect is concluded both where the motivation of the participants is high, the availability of infrastructure, and the required funds. The process aspect was found to work well with various learning methods in learning theory and practice. The product aspect is considered good with the implementation of very precise theory and practice. Research with the CIPP model involved 21 participants and 4 facilitators and 1 organizer (Irwan, 2017). Every aspect is in a good category. In the product aspect, it was found that the organizers were unable to market the results of the trainees' skills. The studies above are relevant to the research carried out. The research carried out is research with the CIPP model. The approach used is different from the research above, namely with a quantitative and qualitative descriptive approach which is carried out at the same time. The context aspect analyzes the suitability of the program with the interests and needs of the community, industrial needs, introduction to the community, the suitability of education, and community experience. The input aspect analyzes all the needs for the implementation of the training program. The process aspect of the training implementation and the product aspect analyze the competence and achievement of the target quantity of the trainees' graduates.

The trainees who have graduated have mastered all the competencies taught by the instructors well and take advantage of the training held so that they are equipped to face the world of work Graduates of UPT BLK Surabaya training participants are expected to be able to compete in the industrial and business world. After almost a year of implementing the post-Covid-19 pandemic training program, the effects and impacts have not been clearly reviewed. The number of graduates from the training program who are already working has not reached the specified target. Some graduates do not work in their areas of competence. Graduates of this level of education do not have special skills as a result of education. Graduates are not prepared to enter the world of work or industry. The training program held at UPT BLK Surabaya needs to be reviewed and evaluated. Based on the description described, it is necessary to evaluate the training program at UPT BLK Surabaya. Training program evaluation research is needed and carried out to find out how well the training program is running for the trainees. The results of the evaluation are expected 
to be able to provide clear considerations and contributions related to decision-making and to provide input for further training programs.

\section{METHODS}

This program evaluation research is aimed at evaluating competency-based training programs organized by the Ministry of Manpower through the UPT BLK Surabaya under the auspices of the East Java Transmigration Manpower Office. This CIPPO program evaluation model is a modification made by (Sax, 1989) from the CIPP program evaluation model developed by (Stufflebeam \& Shinkfield, 1985). The CIPP model is an evaluation model that views the program being evaluated as a system (Jiménez-Becerra \& Segovia-Cifuentes, 2020). Specifically, the context component of the CIPP evaluation model can help identify program implementation and community needs (Molope \& Oduaran, 2020; Salehi et al., 2021; Shou \& Huang, 2020). The CIPPO program evaluation model consists of five evaluation components: context, input, process, product, and outcome, which are an integral part of evaluating the program (Dressel et al., 2020; Jollymore et al., 2018). Outcome is a measure of performance based on the level of success that can be achieved based on the output of programs or activities that have been implemented (Imansari \& Sutadji, 2017; Yuwono et al., 2020). The evaluation of the CIPPO program includes an evaluation of the impact of the program (Jollymore et al., 2018).

In this study, an outcome evaluation examines the absorption and product competence of competency-based training programs in the business and industrial world. The CBT program held at UPT BLK Surabaya became the object of this program evaluation research activity. 199 respondents were consisting of 180 training participants, 19 instructors, consisting of the Head of UPT BLK Surabaya and the Head of Administration, Head of Training and Certification of UPT BLK Surabaya. The data collection technique used in this evaluation research uses a mixed-method research approach (Creswell, 2016). The instruments in this study used document studies, interview guidelines, observation guidelines, and questionnaires. Quantitative data collection in this program evaluation research uses a questionnaire with a Likert scale and has four alternative answers obtained from respondents' assessments. The CIPPO evaluation instrument of UPT BLK Surabaya is presented in Table 1.

Table 1. The CIPP0 Evaluation Instrument of UPT BLK Surabaya

\begin{tabular}{|c|c|}
\hline Aspect & Indicator \\
\hline & Context \\
\hline Foundation training program & $\begin{array}{l}\text { The clear foundation of program objectives against laws, } \\
\text { regulations, and government policies }\end{array}$ \\
\hline $\begin{array}{l}\text { Characteristics of the Training } \\
\text { Program }\end{array}$ & $\begin{array}{l}\text { The principle of the training program is by the Minister of } \\
\text { Manpower Regulation No. } 8 \text { of } 2014\end{array}$ \\
\hline Program Suitability & $\begin{array}{l}\text { There is the suitability of program objectives and identification } \\
\text { of training program needs }\end{array}$ \\
\hline \multicolumn{2}{|r|}{ e } \\
\hline Infrastructure & $\begin{array}{l}\text { The infrastructure and equipment for practice tools and } \\
\text { materials are by the standards of the Minister of Manpower and } \\
\text { Transmigration No. } 8 \text { the Year } 2014\end{array}$ \\
\hline $\begin{array}{l}\text { Training participant selection } \\
\text { process }\end{array}$ & $\begin{array}{l}\text { The selection of training participants was by the Standard } \\
\text { Operating Procedure (SOP) in the Regulation of the Minister of } \\
\text { Manpower and Transmigration No. } 8 \text { the Year } 2014\end{array}$ \\
\hline Instructor competence & $\begin{array}{l}\text { Instructor Competence by the Minister of State Apparatus } \\
\text { Empowerment Regulation No. } 36 \text { of } 2003 \text { concerning Instructor } \\
\text { Functional Positions and Credit Scores }\end{array}$ \\
\hline Curriculum & Competency-based curriculum by SKKNI \\
\hline Fund & Availability of funding during training activities \\
\hline \multicolumn{2}{|l|}{ Process } \\
\hline Training program planning & $\begin{array}{l}\text { The stages of planning the training program are by Ministerial } \\
\text { Regulation No. } 8 \text { of } 2014\end{array}$ \\
\hline $\begin{array}{l}\text { Implementation of training } \\
\text { programs }\end{array}$ & $\begin{array}{l}\text { Implementation of the training program by Ministerial } \\
\text { Regulation No. } 8 \text { of } 2014\end{array}$ \\
\hline $\begin{array}{l}\text { Supervision of the implementation } \\
\text { of the training program }\end{array}$ & $\begin{array}{l}\text { Implementation of monitoring by Ministerial Regulation No. } 8 \text { of } \\
2014 .\end{array}$ \\
\hline
\end{tabular}

Product 


\begin{tabular}{ll}
\hline Aspect & \multicolumn{1}{c}{ Indicator } \\
\hline Competency of trainees & $\begin{array}{l}\text { Participants master the competency units according to the } \\
\text { training program they are participating in }\end{array}$ \\
\hline Outcome & \\
\hline Absorption, graduates, programs, & $\begin{array}{l}\text { Graduates, program, training, placed, in, world, industry, by, } \\
\text { training }\end{array}$ \\
& $\begin{array}{l}\text { 70\%, based on, Standard, Service, Minimum, Employment, for, } \\
\text { Placement Service, Workforce, Work }\end{array}$ \\
\hline
\end{tabular}

The evaluation success criteria are based on the ideal mean score (Xi) and the ideal standard deviation (SBi). While $(\mathrm{X})$ in Table 2 is the average value of the results of calculations on the questionnaire filled out by respondents.

Table 2. The Criteria of Evaluation Assessment

\begin{tabular}{ccc}
\hline No & Score Range & Category \\
\hline 1 & $\mathrm{X} \geq\left(\bar{X}_{\mathrm{i}}+1,8 \mathrm{~S} \mathrm{~B}_{\mathrm{i}}\right)$ & Very good \\
2 & $\left(\bar{X}_{\mathrm{i}}+1,8 \mathrm{SB} \mathrm{B}_{\mathrm{i}}\right)>\mathrm{X} \geq\left(\bar{X}_{\mathrm{i}}+0,6 \mathrm{SB}_{\mathrm{i}}\right)$ & Good \\
3 & $\left(\bar{X}_{\mathrm{i}}+0,6 \mathrm{SB}_{\mathrm{i}}\right)>\mathrm{X} \geq\left(\bar{X}_{\mathrm{i}}-0,6 \mathrm{SB}_{\mathrm{i}}\right)$ & Enough \\
4 & $\left(\bar{X}_{\mathrm{i}}-0,6 \mathrm{~S} \mathrm{~B}_{\mathrm{i}}\right)>\mathrm{X} \geq\left(\bar{X}_{\mathrm{i}}-1,8 \mathrm{SB}_{\mathrm{i}}\right)$ & Not good \\
5 & $\left(\bar{X}_{\mathrm{i}}-1,8 \mathrm{SB} \mathrm{B}_{\mathrm{i}}\right)>\mathrm{X}$ & Very Not good \\
\hline
\end{tabular}

\section{RESULT AND DISCUSSION}

\section{Results}

The research was conducted to determine the achievement of the competency-based training program organized by UPT BLK Surabaya and to be able to provide recommendations and suggestions for the next program. There are 10 vocational programs offered at UPT BLK Surabaya, namely: (1) Electrical Engineering; (2) Electronic Engineering; (3) Information Technology; (4) Automotive Engineering; (5) Manufacturing Engineering; (6) Welding Engineering; (7) Automation Engineering; (8) Tourism; (9) Business Management; and (10) Evaluation research conducted through the collection of quantitative data and qualitative data.

\section{Context Evaluation}

In the context aspect, this evaluation refers to three main components, namely: (1) the basis and objectives of the training program; (2) the characteristics of the training program; and (3) the suitability of the program with the needs of the community, and industry. In the evaluation of the overall context, it can be said and assessed as good because all sub-aspects or components have met the requirements and standards and are by current regulations. The component of implementing competency-based training programs at UPT BLK Surabaya is the suitability of the program to the needs of the community and industry. In planning the training program, UPT BLK Surabaya conducts an Analysis of Training Needs and also carries out the training program in accordance with the SKKNI which in its development is adapted to the needs of the industry. In addition, data collection was also carried out using questionnaires for the program component suitability with the needs of the community and industry. The results of the assessment of respondents consisting of trainees and instructors are shown in Figure 1.

Based on the assessment of the 4 Criteria. UPT BLK Surabaya training program by the institution's objectives (C1), UPT BLK Surabaya training program according to community interest (C2), UPT BLK Surabaya training program according to community needs (C3), UPT BLK Surabaya training program according to industry needs (C4). It can be said that the program according to the needs of the community and industry is stated well according to the participants and well stated according to the instructor. The program is implemented for the community, then the training program is carried out by the interests and needs of the community.

\section{Input Evaluation}

5 components look at the input aspect, namely: (A) infrastructure; (B) the process of accepting training participants; (C) instructor competence; (D) curriculum; and (E) funding. The results of the assessment consisting of trainees and instructors. Based on the data in Figure 2, the average score of the input aspect, infrastructure is 30.06 which is included in the good category. Overall the results of the average score on the input aspect of the infrastructure component which is filled by the instructor are 33.84 including the good category. 


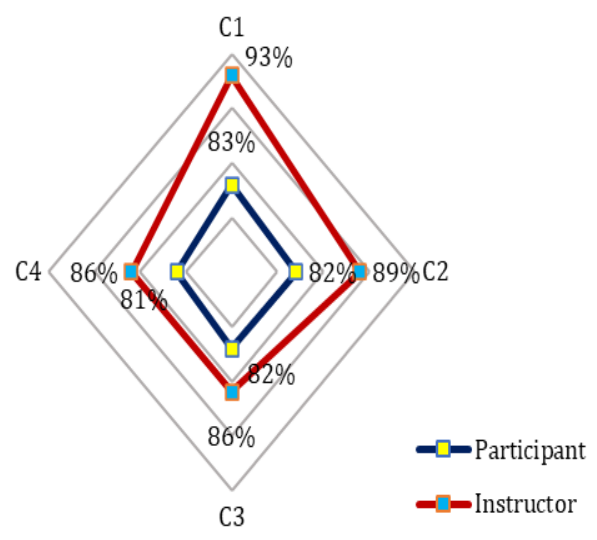

Figure 1. Radar Diagram of Program Suitability with Community and Industry Needs

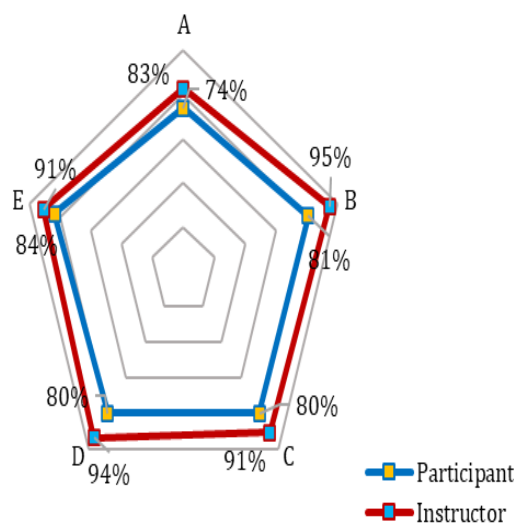

Figure 2. Radar Diagram of Input Aspect

In quantitative data on input aspects related to the selection process for training participants, the criteria are as follows: (I11) program participants are conducted openly and widely, (I12) selection is carried out clearly and transparently. Overall, the average score of the input aspects related to the selection process for the acceptance of training participants is 6.62 and is included in the good category. Based on the data above, the assessment of input aspects related to the selection process for the acceptance of training participants is 7.68, including the very good category. Overall, the average score for the input aspect related to instructor competence is 29.33 and is included in the good category. Overall, the average score on the input aspect of the instructor competency component filled by the instructor was 33.6, including the very good category. The curriculum assessment criteria are (I22) Instructors teach according to the curriculum and SKKNI. The results are as follows: Overall the average score of the input aspects related to the curriculum is 3.22 and is included in the good category. The data from the results of the questionnaire distribution explained that the Criteria for the component (I22) Instructors taught according to the curriculum and by the SKKNI of 3.79 including the very good category. Assessment of input aspects related to funding is carried out using questionnaire data filled out by 180 participants with the following criteria: (I23) training program without fees. Overall, the average related input aspect is 6.8 and is included in the very good category. Based on the data above, the average score for the input aspect related to funds is 7.32 and is included in the very good category.

\section{Process Evaluation}

The process aspect in this evaluation research refers to three main components, namely: 1) training program planning, 2) training program implementation, 3) training program implementation supervision. Based on data collection using documentation, the planning of the CBT training program at UPT BLK Surabaya went well in each vocational. Based on the assessment of the training participants and instructors related to the implementation of the training program at UPT BLK Surabaya, it was good (see Figure 3). Data from the results of questionnaires filled out by the instructor explained that the assessment criteria for the component (P1) suitability of the training schedule and duration were in the very good category, (P2) focused training and according to competency standards included in the very good category, (P3) the instructor was present on time, the participants included very good category, (P4) presenting material clearly including very good category, (P5) directing and motivating, helping solve problems including very good category, (P6) providing learning resources including very good category, (P7) actively supervising training activities including category very good (P8) active, interactive, communicative and efficient learning is included in the very good category.

Overall, the average process aspect related to the implementation of the training program is 25.93 and is included in the good category and by the instructor is 30.16 and is in the very good category. According to the training participants' respondents, the training program implementation process could be further improved. Some instructors sometimes have a habit of not showing up on time or being late. In the 
process of implementing the training program, instructors are expected to be able to actively monitor and supervise the implementation of learning activities. The process of supervision and monitoring carried out at UPT BLK Surabaya for training activities is by the Regulation of the Minister of Manpower and Transmigration No. 8 of 2014. Based on the results of data collection with documentation, each training program has made and compiled a plenary report that attaches administration, preparation, implementation, and assessment results of the trainees. This proves that the administration of the training program implementation process has been accounted for and carried out by regulations.

\section{Product Evaluation}

The product aspect of the training program is the value or learning outcomes of the trainees. Based on data collection with documentation of the assessment of the trainees carried out by observation (see Figure 4), daily evaluation, job sheets, assignments, and practice results. Based on the assessments filled out by participants and instructors related to product aspects, it was obtained in the very good category.

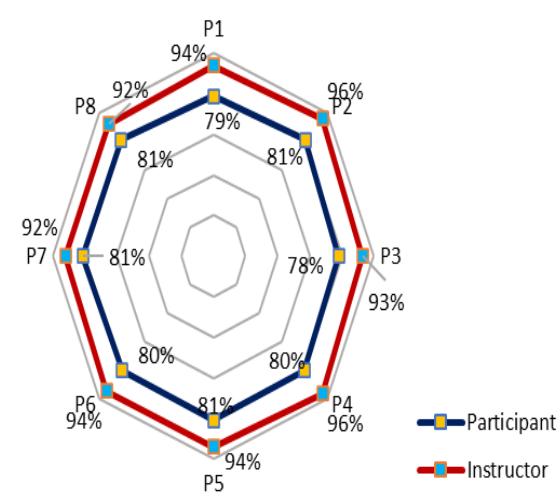

Figure 3. Radar Diagram of Training Program Implementation

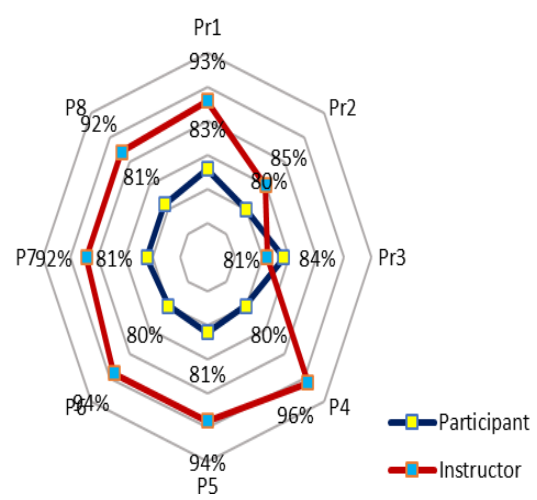

Figure 4. Radar Diagram of Product Aspect

Data from the results of questionnaires filled out by the instructor explained that the assessment criteria for the component (Pr1) of the participants' skills increased including the very good category, (Pr2) the trainees mastered the competencies including the very good category, (Pr3) the selected participants were ready to work and applied their skills including the good category Overall, the average score on the product aspect of the competency component of the trainees filled in by the instructor was 10.42, including the very good category.

\section{Outcomes Evaluation}

The implementation of PBK training at UPT BLK Surabaya certainly produces graduates or products that have the expected competencies of graduates from training programs that can be accepted or absorbed by the industrial world. The training program can be said to be successful if the number of products and results can be absorbed properly and is able to harmonize with the needs of the industry. Based on data collection with documentation conducted in March, the percentage of graduates in 13 programs is presented in Figure 5.

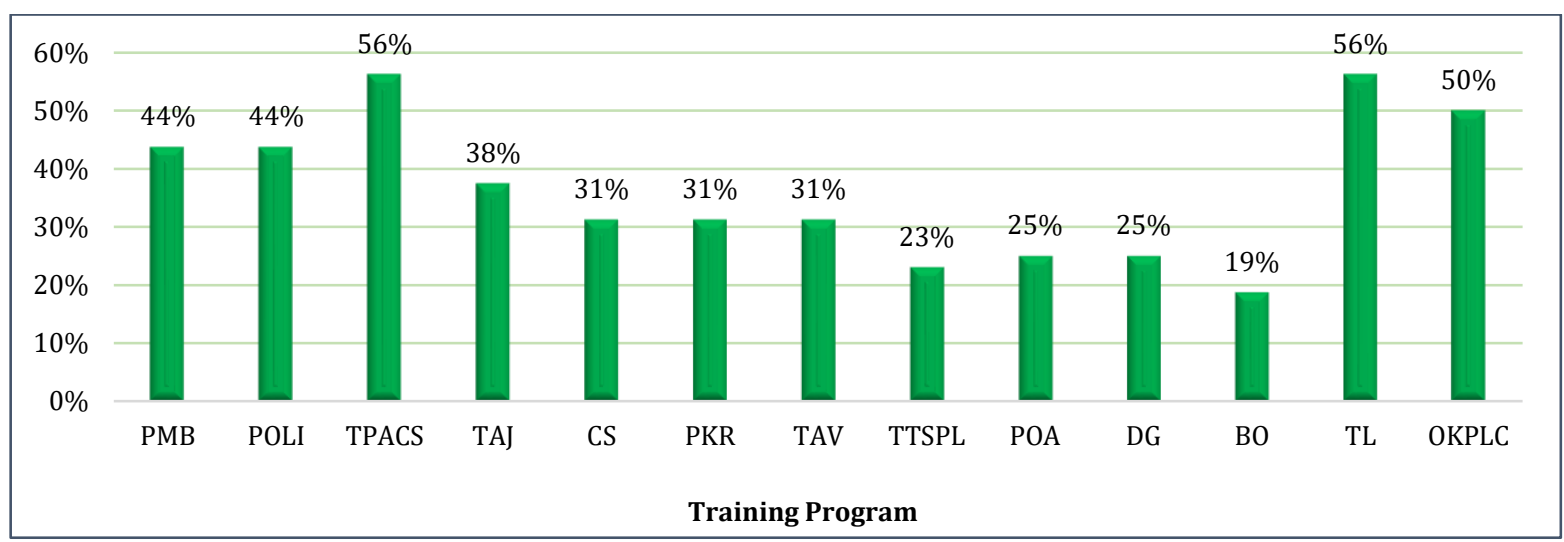

Figure 5. Percentage of Absorption of Training Participants 
Figure 5 shows that the outcome aspects related to the absorption of training participants in each training program are: Lathe Machine Operation (PMB) as many as 7 participants from 16 participants or 44\%, Installation of Industrial Electrical Automation (POLI) as many as 7 participants from 16 participants or 44\%, Split AC Cooling Technique (TPACS) 9 participants from 16 participants or 56\%, Junior Accounting Technician (TAJ) 6 participants from 16 participants or 38\%, Customer Service (CS) 5 participants from 16 participants or 31\%, Maintenance Light Vehicles (PKR) 5 participants from 16 participants or 31\%, Audio Video Engineering (TAV) 5 participants from 16 participants or 31\%, Cellular Phone Software Engineering (TTSPL) 3 participants from 13 participants or 23\%, Practical Office Advance (POA) 4 participants from 16 participants or 25\%, Graphic Design (DG) 4 participants from 16 participants or 25\%, Basic Office (BO) 3 participants from 16 participants or 19\%, Welding Engineering (TL) 9 participants from 16 participants or $56 \%$, Electrical \& Pneumatic PLC Operators (OKPLC)8 participants from 16 participants and or 50\%. Of the 208 participants and the number of graduates consisting of various vocational and competency units, 75 participants, or $36 \%$ are absorbed in the industry.

\section{Discussion}

In the Republic of Indonesia Law Number 20 of 2003, training is held for people who need knowledge, skills, and attitudes to develop themselves, develop their professions, work, independent businesses, and continue their education. One of the roles of the government is as a facilitator so that the community seeks to develop competence and knowledge. This can be met if the training program organized is designed with a focus on the needs of the community. One of the factors that influence competence is the type of training carried out or obtained (Echols et al., 2018). If the training program chosen and carried out is in line with the interests and needs, then the level, mastery, competence is getting higher and higher. His research, shows, there is, a relationship, which, positive, between, motivation, and, level, competence. Participants, training, can motivated, by, because, some, things, for example, understanding, that, program, training, according to, according to, his needs. The CBT training program is not only about producing graduates who have the knowledge and skills. The learner not only acquires knowledge but becomes (Hodge, 2016). Training is not conceptualized as only producing competent graduates, meaning that the institution implementing the training program also has the responsibility to ensure the identity of the graduates of the training program. The government and UPT BLK Surabaya must be able to determine what graduates from the training program will be like. So far, UPT BLK Surabaya has strived to continuously improve the quality of graduates so that it is in line with the needs of DUDI. One of the steps taken is to establish of Communication Forum of Training Institutes with Regional Industries, which one of the objectives is to align the training programs held by UPT BLK Surabaya with the industrial world.

To achieve the objectives of the CBT training program, infrastructure is an important part that is prepared before the implementation of the training program. Infrastructure facilities must meet the needs and standards of each department. Based on the Regulation of the Minister of Manpower and Transmigration Number 8 of 2014, the facilities or infrastructure that must be prepared are equipment, training materials, training places, modules, and references. Based on the assessment of the trainees and instructors, it can be concluded that the process of accepting trainees is very good. The criteria for assessing the process of accepting training participants were stated to be good according to the participants and stated to be very good according to the instructor. The admission process held at UPT BLK Surabaya has complied with the Standard Operating Procedure (SOP) by the Regulation of the Minister of the Ministry of Manpower and Transmigration Number 8 of 2014 which is open, broad, clear, and transparent. Based on data collection with documentation related to the acceptance of training participants, there are complete documents related to the process of receiving training participants at UPT BLK Surabaya are also complete. The readiness and competence of the instructor in conducting the training program influence the success of the training (Dirani, 2012; Kougias et al., 2013). Instructors must be prepared and competent in teaching and training trainees. The requirements that must be met by instructors according to the Regulation of the Minister for Empowerment of State Apparatus No. 36 of 2003 concerning functional positions of instructors and their credit numbers are: 1) Minimum DII education for skilled instructors, and S1 for expert instructors, 2) have a minimum of 2 years' experience in the field of training and education learning 3 ) mastering methodological competencies and technical competencies taught by the CBT curriculum and SKKNI, 4) obtaining a letter of assignment by the Head of the Training Institute, 5) may consist of instructors, experts, or equivalent professions.

Direct supervision at UPT BLK Surabaya has been carried out since training planning starting from the formation of the implementing committee, participant selection, preparation, monitoring of infrastructure and instructors as well as materials for training, and other administration. When the training program is held, it is directly supervised by Internal, in this case, in particular by the Head of UPT BLK Surabaya and the Head of Training and Certification as the person in charge of the training process. 
Meanwhile, direct external supervision is carried out by the Provincial Inspectorate for training programs originating from APBD funds and the Inspectorate General for training programs originating from APBN funds. The results of his research on the effect of training on the performance of participants (Kumara \& Utama, 2016). Training has a positive and significant effect on the performance of the trainees. If the training program has better quality, then the performance of the training employees will also get better. The characteristics of the training are the desire for an increase in skills to do something, the material discussed refers specifically to one competency, the duration is relatively short, and is carried out both in-door and out-door instruction (Pojoh et al., 2014). In his research findings, stated that training has a significant influence on employee performance. Good performance is produced through a good training program. If the training program is implemented according to the needs in the world of work, it can be ascertained that graduates are ready to enter the world of work and have good performance.

After completing the training program, the trainee has passed or is competent, then the participant has entered a new phase, namely industry. How well the level of absorption of graduates from training programs in the industry is the outcome of the training program (Sudira, 2016). It is not enough for training institutions to only educate and train participants to graduate. Training institutions should be obliged to connect graduates with industry. One of the steps taken by UPT BLK Surabaya is to establish cooperation with the industrial world. The training program can be said to be successful if the number of products and outcomes can be well absorbed and able to harmonize with industry needs. Based on data collection with documentation related to the absorption of graduates taken in March, of the 208 participants and the number of graduates consisting of various vocational and competency units, only 75 participants, or $36 \%$ were absorbed into the industry. This is very low considering the number of graduates who are still unemployed is greater than graduates who have been absorbed into the industry. There are many factors that make the absorption rate of graduate's low, one of the most influential is the Covid-19 pandemic. The Covid-19 pandemic has made unemployment in Indonesia soar high and caused the Indonesian economy to experience a recession (Zubaidi et al., 2014), this is partly due to the government's appeal and policy to carry out social distancing, limit working hours, and limit the capacity of workers who enter by means of Work From Home even a few months ago the government issued Government Regulation Number 21 of 2020 concerning Large-Scale Social Restrictions to minimize the number of Covid-19 spreads. This makes the productivity of a company and industry decline so that some companies and industries reduce the number of employees so that some companies do not open new employee recruitment which makes the number of jobs a little less.

\section{CONCLUSION}

The suitability of the context evaluation resulted in a very good program with the goals of the Institute, the needs of the community, and industry. The selection process for the acceptance of training participants is in the very good category and is open, broad, and transparent in accordance with the Regulation of the Minister of Manpower Number 8 of 2014. Instructor competence is declared good by the participants and very good by the instructor. All instructors at UPT BLK Surabaya have met the requirements and performed their duties in accordance with the regulations. Funding in the very good category. The trainees undergo a training program at no cost and the funding needs of the program are adequate. In the evaluation process, the assessment filled out by the training participants was in a good category and the assessment filled out by the instructor regarding the implementation of the training program was in the very good category. However, there are things that need to be improved, namely, some instructors sometimes don't show up on time and sometimes leave the class. In the product aspect, the competence of the trainees was declared very good by the participants and very good by the instructors. There are many factors behind it but the most influential factor is the result of the COVID-19 pandemic. However, the UPT BLK Surabaya can add competencies and insights related to the business world into the training program. It is better not only to identify training programs with the industrial world but also to identify based on community needs so that training participants can be more flexible to enter the business world. Many found in the questionnaire notes and suggestions from the training participants that it was necessary to increase the cleanliness of the toilets and the number of toilets so that the trainees were more comfortable in undergoing the training program.

\section{REFERENCES}

Coetzer, A., Susomrith, P., \& Ampofo, E. T. (2020). Opportunities to participate in formal and informal vocational learning activities and work-related outcomes in small professional services businesses. 
Journal of Vocational Education \& Training, $72(1), \quad 88-114$. https://doi.org/10.1080/13636820.2019.1584637.

Creed, P. A., Hood, M., \& Hu, S. (2020). Job crafting by students who work and study. International Journal for Educational and Vocational Guidance, 20(2), 331-349. https://doi.org/10.1007/s10775-01909406-2.

Creswell, J. W. (2016). Research Design: Pendekatan Metode Kualitatif, Kuantitatif, dan Campuran (Edisi 4). Pustaka Belajar.

Daryono, R. W., Hariyanto, V. L., \& Usman, H. (2020). Factor analysis: Competency framework for measuring student achievements of architectural engineering education in Indonesia. REID (Research and Evaluation in Education), 6(2), 98-108. https://doi.org/10.21831/reid.v6i2.32743.

Daryono, R. W., Rochmadi, S., \& Hidayat, N. (2021). Development and validation of video-based learning media to increase competency achievement in civil engineering education. Journal of Physics: Conference Series, 1833(1), 012022. https://doi.org/10.1088/1742-6596/1833/1/012022.

Dirani, K. M. (2012). Professional training as a strategy for staff development: A study in training transfer in the Lebanese context. European Journal of Training and Development, 36(2/3), 158-178. https: //doi.org/10.1108/03090591211204698.

Djatmiko, I. W. (2018). Strategi Penulisan Skripsi, Tesis, \& Disertasi Bidang Pendidikan. UNY Press

Dressel, S., Ericsson, G., Johansson, M., Kalén, C., Pfeffer, S. E., \& Sandström, C. (2020). Evaluating the outcomes of collaborative wildlife governance: The role of social-ecological system context and collaboration dynamics. Uand Policy, 99, 1-13. https://doi.org/10.1016/j.landusepol.2020.105028.

Echols, D. G., Neely, P. W., \& Dusick, D. (2018). Understanding faculty training in competency-based curriculum development. The Journal of Competency-Based Education, 3(2), 1-9. https: //doi.org/10.1002/cbe2.1162.

García-Castilla, F. J., De-Juanas Oliva, Á., Vírseda-Sanz, E., \& Páez Gallego, J. (2019). Educational potential of e-social work: Social work training in Spain. European Journal of Social Work, 22(6), 897-907. https: //doi.org/10.1080/13691457.2018.1476327.

Hodge, S. (2016). After competency-based training: Deepening critique, imagining alternatives. International Journal of Training Research, 14(3), 171-179. https://doi.org/10.1080/14480220.2016.1261432.

Hofmann, C., Häfeli, K., Müller, X., \& Krauss, A. (2021). Transition from Low-Threshold Vocational Education and Training to Work in Switzerland: Factors Influencing Objective and Subjective Career Success. International Journal for Research in Vocational Education and Training, 8(2), 136-159. https://doi.org/10.13152/IJRVET.8.2.1.

Imansari, N., \& Sutadji, E. (2017). A Conceptual Framework Curriculum Evaluation Electrical Engineering Education. International Journal of Evaluation and Research in Education (IJERE), 6(4), 265-269. https://eric.ed.gov/?id=EJ1166885.

Irwan,, M., (2017)., Evaluasi, Program, Pelatihan, Pengolahan, Lembah, Kertas, Semen, Pada, Pusat, Kegiatan, Belajar, Masyarakat, (PKBM), Cahaya, Kota, Binjai. https://journal.uny.ac.id/index.php/jppm/article/view/14100/pdf.

Jiménez-Becerra, I., \& Segovia-Cifuentes, Y.-M. (2020). Models of didactic integration with ICT mediation: Some innovation challenges in teaching practices (Modelos de integración didáctica con mediación TIC: algunos retos de innovación en las prácticas de enseñanza ). Culture and Education, 32(3), 399440. https://doi.org/10.1080/11356405.2020.1785140.

Jollymore, A., McFarlane, K., \& Harris, L. M. (2018). Whose input counts? Evaluating the process and outcomes of public consultation through the BC Water Act Modernization. Critical Policy Studies, 12(4), 381-405. https://doi.org/10.1080/19460171.2017.1282377.

Kougias, I., Seremeti, L., \& Kalogeras, D. (2013). Mobility of Eastern European citizens: Training and development. European Journal of Training and Development, 37(8), 766-778. https://doi.org/10.1108/EJTD-03-2013-0033.

Kumara, I. W. S. E., \& Utama, I. W. M. (2016). Pengaruh Pelatihan terhadap Kinerja Karyawan dengan Mediasi Kepimpinan pada Hotel Satriya Cottages Kuta-Bali. E-Jurnal Manajemen Unud, 5(3), 1399-1428. https://ojs.unud.ac.id/index.php/Manajemen/article/download/19162/13142.

Meo, M. S., Kumar, B., Chughtai, S., Khan, V. J., Dost, M. K. B., \& Nisar, Q. A. (2020). Impact of Unemployment and Governance on Poverty in Pakistan: A Fresh Insight from Non-linear ARDL Co-integration Approach. Global Business Review, 1-18. https://doi.org/10.1177/0972150920920440.

Molope, M., \& Oduaran, A. (2020). Evaluation of the community development practitioners' professional development programme: CIPP model application. Development in Practice, 30(2), 194-206. https://doi.org/10.1080/09614524.2019.1650894. 
Nopiah, M., Sattar, M., \& Ismail, K. (2018). Challenges Faced by Vocational Teachers in Public Skills Training Institutions: A Reality in Malaysia. Journal of Technical Education and Training, 10(2). https://doi.org/10.30880/jtet.2018.10.02.002.

Nurtanto, M., Arifin, Z., Sofyan, H., Warju, W., \& Nurhaji, S. (2020). Development of Model for Professional Competency Assessment (PCA) in Vocational Education: Study of the Engine Tune-Up Injection System Assessment Scheme. Journal of Technical Education and Training, 12(2), 34-45. https://doi.org/10.30880/jtet.2020.12.02.004.

Pamungkas, A. \& Fauziah, P.Y. (2014). Evaluasi Program Kewirausahaan Bengkel Pada Kerja Paket B di PKBM Tunas Bangsa Tugu Semarang. Jurnal Pendidikan dan Pemberdayaan Masyarakat, 4(2). https://journal.uny.ac.id/index.php/jppm/article/view/2684/2237.

Pojoh, T. P., Tewal, B., \& Moniharapon, S. (2014). Pengaruh Pendidikan dan Pelatihan (DIKLAT) terhadap Kinerja Karyawan PT PLN (PERSERO) Wilayah Sulutenggo. Jurnal EMBA, 2(4), 424-434. https://ejournal.unsrat.ac.id/index.php/emba/article/view/6346.

Prasojo, L. D., Habibi, A., Mukminin, A., Sofyan, S., Indrayana, B., \& Anwar, K. (2020). Factors Influencing Intention to Use Web 2.0 in Indonesian Vocational High Schools. International Journal of Emerging Technologies in Learning (IJET), 15(05), 100. https://doi.org/10.3991/ijet.v15i05.10605.

Pratomo, H., Priyambodo, E., \& Wiyarsi, A. (2020). Vocational High School Students Chemical Literacy on Context-Based Learning: A Case of Petroleum Topic. Turkish Journal of Science Education, 17(1), 147-161. https://doi.org/10.36681/tused.2020.18.

Salehi, M., Abbasi, E., Bijani, M., \& Shahpasand, M. R. (2021). Evaluation of agricultural extension model sites approach in Iran. Journal of the Saudi Society of Agricultural Sciences, 1, 1-15. https://doi.org/10.1016/j.jssas.2021.06.002.

Sax, G. (1989). Principles of educational and psychological measurement and evaluation (3rd Ed.). Wadsworth.

Shou, K. J., \& Huang, C. C. (2020). Numerical analysis of straight and curved underground pipeline performance after rehabilitation by cured-in-place method. Underground Space, 5(1), 30-42. https://doi.org/10.1016/j.undsp.2018.10.003.

Stufflebeam, D., \& Shinkfield, A. (1985). Systematic Evaluation. Kluwer Nijihof Publishing.

Sudira, P. (2016). TVET abad XXI: Filosofi, teori, konsep, dan strategi pembelajaran vokasional. UNY

Supriyadi, E., Indro H., Y., Priyanto, E., \& Surwi, F. (2020). Students' Evaluation on Teaching in Vocational and Technical Schools. International Journal of Instruction, 13(2), 621-636. https://doi.org/10.29333/iji.2020.13242a.

Triyono, B. M., Mohib, N., Kassymova, G. K., Pratama, G. N. I. P., Adinda, D., \& Arpentieva, M. R. (2020). The Profile Improvement of Vocational School Teachers' Competencies. Vysshee Obrazovanie $v$ Rossii $=$ Higher Education in Russia, 29(2), 151-158. https://doi.org/10.31992/0869-3617-2020-29-2151-158.

Yuwono, I., Syahrin, M. N. A., Rachman, D., Budhi, S., \& Hairini, S. M. (2020). The Evaluation of Inclusive Education Program Through CIPPO Approach. Journal of Critical Reviews, 7(4), 1-7.

Zubaidi, N., Pratama, R. G., \& Al-Fatih, S. (2020). Legal Perspective on Effectiveness of Pre-Work Cards for Indonesian People. BESTUUR, 8(1), 9-18. https://doi.org/10.20961/bestuur.v8i1.42722. 